\title{
Performance of Green Type Eggplant in Relation of Insect and Diseases
}

\author{
Akm Quamruzzaman ${ }^{*}$, Ferdouse Islam¹, M. Nazim Uddin1, Mohammad Aziz Zilani Chowdhury² \\ ${ }^{1}$ Olericulture Division, Horticulture Research Centre, Bangladesh Agricultural Research Institute, Gazipur, Bangladesh \\ ${ }^{2}$ Bangladesh Agricultural Research Council, Dhaka, Bangladesh \\ Email: *akmqzs@gmail.com
}

How to cite this paper: Quamruzzaman, A., Islam, F., Uddin, M.N. and Chowdhury, M.A.Z. (2019) Performance of Green Type Eggplant in Relation of Insect and Diseases. American Journal of Plant Sciences, 10, 139-146.

https://doi.org/10.4236/ajps.2019.101012

Received: November 14, 2018

Accepted: January 15, 2019

Published: January 18, 2019

Copyright (c) 2019 by author(s) and Scientific Research Publishing Inc. This work is licensed under the Creative Commons Attribution International License (CC BY 4.0).

http://creativecommons.org/licenses/by/4.0/

\begin{abstract}
The study was conducted with 18 eggplant lines/variety at the farm of Olericulture Division, HRC, Bangladesh Agricultural Research Institute, Gazipur during the winter season of 2017-18 to develop new green type high yielding OP variety having tolerance to eggplant fruit and shoot borer and bacterial wilt. The lines varied significantly for their response to all characters $(\mathrm{P}<$ 0.05). The lineSM 083F required minimum 105 days to first harvest. Maximum marketable fruit number was obtained by SM083A (30.33). Heavy sized fruit was harvested by SM275 (175 g), followed by SM289 (170 g), SM279 (169 g), SM083E (165 g), SM253 (164 g). The range of fruit infection by BFSB was $10.33 \%-19.007 \%$, while lowest in SM262 (10.33\%). In case of bacterial wilt (BW) infestation at field level performance, zero percent incidence was observed in SM262, SM275, SM279, SM291B. The yield range of eggplant lines was $18.62-43.36 \mathrm{t} / \mathrm{ha}$. The highest fruit yield was recorded from the line SM 275 (43.36 t/ha), which was statistically similar with which was statistically similar with SM 279 (39.85 t/ha), SM 291B (38.59 t/ha), SM083B (38.42 t/ha), SM 262 (38.17 t/ha), SM 253 (37.43 t/ha). Considering earliness, tolerance to fruit infection by BFSB, bacterial wilt infestation, attractive fruit shape and fruit colour, the lines SM 275, SM 279, SM 291B, SM083B, SM 262, SM 253 were found promising. So these six lines can be selected for further confirmation.
\end{abstract}

\section{Keywords}

Performance, Green, Eggplant, Yield, Insect and Diseases

\section{Introduction}

Eggplant or brinjal or aubergine belongs to the family Solanaceae and under the 
botanical name Solanum melongena L. [1]. It is a major vegetable crop throughout the tropic and subtropics [2]. Eggplant (Solanum melongena L.) is the most popular vegetable crop in respect of total acreage (50,415 hectare) and production (504,817 metric ton) in Bangladesh with an average yield of 10.0 metric tons per hectare [3], which is very low as compared to that in other tropical countries. This low yield may be due to lack of high yielding varieties with pest resistance. High yielding variety is an important factor for maximizing the yield of eggplant.

Brinjal or eggplant is an important solanaceous crop of sub tropics and tropics. The name brinjal is popular in Indo-Bangla subcontinents and is derived from Arabic and Sanskrit whereas the name eggplant has been derived from the shape of the fruit of some varieties, which are white and resemble in shape to chicken eggs. It is also called aubergine (French word) in Europe. The eggplant is of much importance in the warm areas of Far East, being grown extensively in India, Bangladesh, Pakistan, China and the Philippines. It is also popular in Egypt, France, Italy and United States. In India, Bangladesh it is one of the most common, popular and principal vegetable crops grown throughout the country. It is a versatile crop adapted to different agro-climatic regions and can be grown throughout the year.

Eggplant is rich in calories, protein, carbohydrate, fiber, vitamins, minerals, antioxidants, flavonoids etc. One cup of cooked eggplant, weighing around 99 grams (g) contains: 35 calories, $0.82 \mathrm{~g}$ of protein, $8.64 \mathrm{~g}$ of carbohydrate, of which $3.17 \mathrm{~g}$ is sugars, $0.23 \mathrm{~g}$ of fat, $2.5 \mathrm{~g}$ of dietary fiber, $188 \mathrm{mg}$ of potassium, 6 $\mathrm{mg}$ of calcium, $1 \mathrm{mg}$ of sodium, $0.12 \mathrm{mg}$ of zinc, $1.3 \mathrm{mg}$ of vitamin C, $0.25 \mathrm{mg}$ of iron, $11 \mathrm{mg}$ of magnesium, $15 \mathrm{mg}$ of phosphorus, 14 micrograms (mcg) of folate, $85 \mathrm{mcg}$ of vitamin B6, $2.9 \mathrm{mcg}$ of vitamin K. Eggplants also contain flavonoids, such as anthocyanins. Anthocyanins are water-soluble pigments that have many health benefits. They also help give the eggplant its well-known, dark purple color. The skin of the eggplant is rich in antioxidants, fiber, potassium, and magnesium. The phenolic content of eggplant makes it such a potent free radical scavenger that this vegetable is ranked among the top 10 vegetables in terms of oxygen radical absorbance capacity. The fiber, potassium, vitamin C, vitamin B6, and phytonutrient content in eggplants all support heart health. Certain flavonoids, including anthocyanins, may be associated with a lower risk of mortality from heart disease [4]. Eggplant juice led to significantly lower weight and blood cholesterol levels. Anthocyanins and chlorogenic acid has been shown to decrease low-density lipid (LDL) levels as well also acts as an antimicrobial, antiviral, and anti-carcinogenic agent and anti-cancer effects. Anthocyanin in the eggplant skin is a powerful antioxidant that protects brain cell membranes from free radical damage, neuro-inflammation and facilitate blood flow to the brain. This could help improve memory and prevent age-related mental disorders.

Besides this, the following are some advantages of green eggplant, as we explore. Green eggplant is beneficial for maintaining healthy blood vessels, nourishes blood boats and makes you relaxed avoid the nervousness, eliminating 
convulsions, nervous and nerve spasms. The green eggplant is also used as an ingredient for pain relief and it is more famous as food for preventing cancer. This vegetable can prevent and even reduce damage to the cells with chromosomal storage as a sign of cancer in the body [5].

A number of cultivars are grown in Bangladesh, consumer preference being dependent upon fruit colour, size and shape. We are accustomed to purple eggplant, but in addition to purple eggplant, there is also green eggplant. Green eggplant vegetable usually made as a complement to the cuisine, but not only that because green eggplant also saves a lot of benefits for health. Green eggplant plant is still included in the Solanaceae family and the Solanum genus. The green eggplant is native to Bangladesh, Sri Lanka and India, generally grown on an annual basis because these plants are rather old age. Green eggplant typically planted to complement the cuisine, but also provides some of the health benefits of green eggplant. But there is a great problem of insect and diseases while eggplant is cultivating in Bangladesh. The main problems are fruit and shoot infection by brinjal fruit and shoot borer (BFSB) [Leucinodes orbonalis] and bacterial wilt [Psedomonas solancearum], little leaf [Phytoplasma], phomopsis blight [Phomopsis vexans] infestation. Sometime $80 \%-90 \%$ yield loss is observed in Bangladesh. That is why it is very much needed to develop or identify eggplant varieties tolerant to these problems.

There is a great chance to get higher yield by collecting new germplasm of eggplant. With this information in mind, Olericulture division collected a lot of green coloured eggplant germplasm and evaluated during last 2 years and developed 18 high yielder green coloured eggplant lines. This study was undertaken to study the performance of these green coloured eggplant lines regarding yield and having tolerance to eggplant fruit and shoot borer, bacterial wilt and phomopsis blight.

\section{Materials and Methods}

The experiment was conducted at the experimental farm of Joydebpur during the winter of $2017-18$. The experimental field was at $23.9917^{\circ} \mathrm{N}$ Latitude and $90.4124^{\circ} \mathrm{E}$ Longitudes having an elevation of $8.2 \mathrm{~m}$ from sea level. Eighteen eggplant lines/varieties viz., SM048, SM083, SM083A, SM083B, SM083E, SM083G, SM083H, SM083F, SM220, SM230, SM253, SM253A, SM262, SM275, SM279, SM289, SM291B, BARI Begun-6 included in the study as check. The seeds were sown on the seedbed on 22 September 2017. Thirty-five days old seedlings were transplanted in the main field on 07 November, 2017. The experiment was laid out in a RCB design with three replications. The unit plot size was $7.5 \times 0.70 \mathrm{~m}$ and 10 plants were accommodated in a plot with a plant spacing of $75 \mathrm{~cm}$ apart in single row maintaining a row to row distance of $1 \mathrm{~m}$ with $50 \mathrm{~cm}$ drain. The land was fertilized with cowdung, N, P, K, S, Zn and B @ $10,000,100,30,75,13,1.5$ and $0.8 \mathrm{~kg} / \mathrm{ha}$, respectively. One third of the cow-dung and half of $\mathrm{P}$ and full of $\mathrm{S}, \mathrm{Zn}$ and $\mathrm{B}$ were applied during final land preparation. Rest of cow-dung and $\mathrm{P}$ and $1 / 3$ of $\mathrm{K}$ were applied as basal in pit. 
Entire amount of $\mathrm{N}$ and rest of $\mathrm{K}$ were applied in four equal installment starting from 20 days after transplanting. Rest three installments were applied at vegetative, flowering and initial fruiting stage. Irrigation, weeding, crop protection measures and other intercultural operations were done following standard practice. Data on days to 1 st harvest, marketable fruit number/plant, average fruit weight $(\mathrm{g})$, fruit weight/plant $(\mathrm{kg})$, fruit length $(\mathrm{cm})$, fruit diameter $(\mathrm{cm})$, plant height at 1 st harvest $(\mathrm{cm})$, plant height at last harvest $(\mathrm{cm})$, fruit infection by BFSB (\%), bacterial wilt infestation (\%), little leaf infestation (\%), phomopsis blight infestation (\%), fruit yield ( $\mathrm{t} / \mathrm{ha})$, fruit shape and fruit colour were recorded from five randomly selected plants per entry per replication. The information on different characters was statistically analyzed.

Fruit infection by BFSB was calculated by: Eggplant fruits were sorted in every harvest and total infected fruit was counted and make it total. Fruit infection by BFSB $(\%)=($ Weight of total infected fruit/Total weight fruits $) \times 100$ (in per cent).

Bacterial wilt infestation was calculated by: Eggplant plants were identified with bacterial wilt infestation from total plant number. Plant infestation by bacterial wilt $(\%)=($ Number of total bacterial wilt infested plant/Total number of plant) $\times 100$ (in per cent).

Little leaf infestation was calculated by: Eggplant plants were identified with little leaf infestation from total plant number. Plant infestation by Little leaf (\%) $=($ Number of total little leaf infested plant $/$ Total number of plant $) \times 100$ (in per cent).

Phomopsis blight infestation was calculated by: Eggplant plants were identified with Phomopsis blight infestation from total plant number. Plant infestation by Phomopsis blight $(\%)=$ (Number of total Phomopsis blight infested plant/ Total number of plant) $\times 100$ (in per cent).

\section{Results and Discussion}

Mean performances of eggplant lines/varieties are presented in Table 1, Table 2 and Figure 1. The lines varied significantly for their response to days to 1 st harvest, marketable fruit number/plant, average fruit weight, fruit weight/plant, fruit length, fruit diameter, plant height at 1st harvest, plant height at last harvest, fruit infection by BFSB, bacterial wilt infestation, fruit yield $(P<0.05)$. In respect of days to first harvest, the earliest line was SM083F (105.0 days) which was statistically similar with SM220 (105.3 days) and followed by SM083 (105.7 days), SM275 (107.7 days) and SM289 was the most delayed (116.3 days).The predominance of additive genetic control earliness in eggplant [6] [7] [8]. The range of marketable fruit number was (16.36 - 30.33). The highest marketable fruit number per plant was counted in SM083A (30.33) which was statistically similar with SM230 (29.33), SM220 (28.66), SM083H (27.93), SM083F (25.00), SM262 (24.33), while lowest fruit number was counted in SM083E (16.36). Average fruit weight is an important criterion to select a high yielder line. The heaviest fruit was produced in SM275 (175 g), which was statistically similar with 
Table 1. The yield and yield contributing characters of 18 eggplant lines/variety.

\begin{tabular}{|c|c|c|c|c|c|c|}
\hline Treatment & $\begin{array}{l}\text { Days to } \\
\text { 1st harvest }\end{array}$ & $\begin{array}{c}\text { Marketable } \\
\text { fruit } \\
\text { number/plant }\end{array}$ & $\begin{array}{c}\text { Average } \\
\text { fruit weight } \\
\text { (g) }\end{array}$ & $\begin{array}{c}\text { Fruit } \\
\text { weight/plant } \\
(\mathrm{kg})\end{array}$ & $\begin{array}{l}\text { Fruit } \\
\text { length } \\
(\mathrm{cm})\end{array}$ & $\begin{array}{c}\text { Fruit } \\
\text { diameter } \\
(\mathrm{cm})\end{array}$ \\
\hline SM048 & 108.0 a-e & $28.53 \mathrm{a}-\mathrm{c}$ & $92 \mathrm{fg}$ & $2.56 \mathrm{~d}-\mathrm{f}$ & $13.67 \mathrm{~b}-\mathrm{d}$ & $4.30 \mathrm{gh}$ \\
\hline SM083 & $105.7 \mathrm{c}-\mathrm{e}$ & 24.46 a-e & $84 \mathrm{gh}$ & $2.09 \mathrm{fg}$ & $17.10 \mathrm{a}$ & $4.27 \mathrm{gh}$ \\
\hline SM083A & $113.0 \mathrm{a}-\mathrm{d}$ & $30.33 \mathrm{a}$ & $101 \mathrm{ef}$ & $3.08 \mathrm{~b}-\mathrm{e}$ & $17.33 \mathrm{a}$ & $5.80 \mathrm{f}$ \\
\hline SM083B & $107.7 \mathrm{~b}-\mathrm{e}$ & $24.00 \mathrm{~b}-\mathrm{e}$ & $147 \mathrm{~d}$ & $3.49 \mathrm{ab}$ & $15.17 \mathrm{ab}$ & $5.57 \mathrm{f}$ \\
\hline SM083E & $114.7 \mathrm{ab}$ & $16.36 \mathrm{~g}$ & $165 a-c$ & $2.69 \mathrm{c}-\mathrm{f}$ & $10.53 \mathrm{e}-\mathrm{h}$ & $5.93 \mathrm{ef}$ \\
\hline SM083F & $105.0 \mathrm{de}$ & 25.00 a-e & $68 \mathrm{~h}$ & $1.69 \mathrm{~g}$ & 10.33 e-h & $6.30 \mathrm{~d}-\mathrm{f}$ \\
\hline SM083G & 109.4 a-e & $22.16 \mathrm{~d}-\mathrm{g}$ & $110 \mathrm{e}$ & $2.45 \mathrm{ef}$ & $11.70 \mathrm{~d}-\mathrm{g}$ & $7.03 \mathrm{c}-\mathrm{e}$ \\
\hline SM083H & 111.9 a-e & $27.93 \mathrm{a}-\mathrm{d}$ & $93 \mathrm{fg}$ & $2.60 \mathrm{~d}-\mathrm{f}$ & $10.40 \mathrm{e}-\mathrm{h}$ & $7.30 \mathrm{~cd}$ \\
\hline SM220 & $105.3 \mathrm{de}$ & $28.66 \mathrm{a}-\mathrm{c}$ & $88 \mathrm{fg}$ & $2.51 \mathrm{~d}-\mathrm{f}$ & $10.43 \mathrm{e}-\mathrm{h}$ & $3.60 \mathrm{~h}$ \\
\hline SM230 & 108.3 a-e & $29.33 \mathrm{ab}$ & $78 \mathrm{gh}$ & $2.3 \mathrm{fg}$ & $8.40 \mathrm{~h}$ & $7.67 \mathrm{~b}-\mathrm{d}$ \\
\hline SM253 & $111.3 \mathrm{a}-\mathrm{e}$ & $20.66 \mathrm{e}-\mathrm{g}$ & $164 \mathrm{a}-\mathrm{c}$ & $3.40 \mathrm{a}-\mathrm{c}$ & $12.00 \mathrm{c}-\mathrm{f}$ & $7.27 \mathrm{~cd}$ \\
\hline SM253A & $114.0 \mathrm{a}-\mathrm{c}$ & $22.00 \mathrm{~d}-\mathrm{g}$ & $143 \mathrm{~d}$ & $3.14 \mathrm{~b}-\mathrm{e}$ & $8.33 \mathrm{~h}$ & $4.00 \mathrm{~h}$ \\
\hline SM262 & $113.3 \mathrm{a}-\mathrm{d}$ & 24.33 a-e & $143 \mathrm{~d}$ & $3.47 \mathrm{ab}$ & $13.67 \mathrm{~b}-\mathrm{d}$ & $9.50 \mathrm{a}$ \\
\hline SM275 & 107.7 b-e & $22.66 c-f$ & $175 \mathrm{a}$ & $3.94 \mathrm{a}$ & $14.67 \mathrm{a}-\mathrm{c}$ & $5.33 \mathrm{fg}$ \\
\hline SM279 & 113.0 a-d & $21.33 \mathrm{e}-\mathrm{g}$ & $169 \mathrm{ab}$ & $3.63 \mathrm{ab}$ & $9.17 \mathrm{gh}$ & $8.50 \mathrm{ab}$ \\
\hline SM289 & $116.3 \mathrm{a}$ & $19.00 \mathrm{e}-\mathrm{g}$ & $170 \mathrm{a}$ & $3.20 \mathrm{~b}-\mathrm{d}$ & $9.33 \mathrm{f}-\mathrm{h}$ & $9.43 \mathrm{a}$ \\
\hline SM291B & 111.7 a-e & $23.33 \mathrm{~b}-\mathrm{e}$ & $151 \mathrm{~cd}$ & $3.51 \mathrm{ab}$ & $15.83 \mathrm{ab}$ & $7.37 \mathrm{~cd}$ \\
\hline BARI Begun-6 & $103.7 \mathrm{e}$ & $17.00 \mathrm{fg}$ & $153.7 \mathrm{bcd}$ & $2.59 \mathrm{~d}-\mathrm{f}$ & $12.33 \mathrm{c}-\mathrm{e}$ & $7.67 \mathrm{bc}$ \\
\hline $\begin{array}{c}\text { Level of } \\
\text { significance }\end{array}$ & * & * & * & * & * & * \\
\hline CV (\%) & 4.63 & 15.87 & 7.58 & 15.22 & 13.25 & 11.31 \\
\hline
\end{tabular}

${ }^{*}$ Significant at $5 \%$ level of probability; ${ }^{*}$ Significant at $1 \%$ level of probability. Means in a column followed by the same letters are not significantly different at $1 \%$ level by DMRT.

\begin{tabular}{ccccccc}
\hline Treatment & $\begin{array}{c}\text { Plant } \\
\text { height at } 1^{\text {st }} \\
\text { harvest }(\mathrm{cm})\end{array}$ & $\begin{array}{c}\text { Plant height } \\
\text { at last } \\
\text { harvest }(\mathrm{cm})\end{array}$ & $\begin{array}{c}\text { Fruit } \\
\text { infection by } \\
\text { BFSB (\%) }\end{array}$ & $\begin{array}{c}\text { Bacterial } \\
\text { wilt } \\
\text { infestation } \\
(\%)\end{array}$ & $\begin{array}{c}\text { Little leaf } \\
\text { infestation } \\
(\%)\end{array}$ & $\begin{array}{c}\text { Phomopsis } \\
\text { blight } \\
\text { infestation } \\
(\%)\end{array}$ \\
\hline SM048 & $61.77 \mathrm{bc}$ & $80.43 \mathrm{bc}$ & $13.67 \mathrm{~d}-\mathrm{f}$ & $3.33 \mathrm{ab}$ & 0 & 0 \\
SM083 & $58.57 \mathrm{bc}$ & $82.83 \mathrm{bc}$ & $16.00 \mathrm{bc}$ & $6.67 \mathrm{ab}$ & 0 & 0 \\
SM083A & $52.67 \mathrm{c}-\mathrm{e}$ & $77.90 \mathrm{bc}$ & $12.33 \mathrm{fg}$ & $6.67 \mathrm{ab}$ & 0 & 0 \\
SM083B & $56.67 \mathrm{~b}-\mathrm{d}$ & $86.87 \mathrm{~b}$ & $16.67 \mathrm{ab}$ & $3.33 \mathrm{ab}$ & 0 & 0 \\
SM083E & $66.50 \mathrm{ab}$ & $100.27 \mathrm{a}$ & $10.67 \mathrm{~g}$ & $10.00 \mathrm{ab}$ & 0 & 0 \\
SM083F & $44.67 \mathrm{~d}-\mathrm{f}$ & $73.33 \mathrm{~cd}$ & $16.33 \mathrm{~b}$ & $3.33 \mathrm{ab}$ & 0 & 0 \\
SM083G & $57.10 \mathrm{~b}-\mathrm{d}$ & $78.97 \mathrm{bc}$ & $16.00 \mathrm{bc}$ & $13.33 \mathrm{a}$ & 0 & 0 \\
\hline
\end{tabular}




\begin{tabular}{|c|c|c|c|c|c|c|}
\hline \multicolumn{7}{|l|}{ Continued } \\
\hline SM083H & $50.27 \mathrm{c}-\mathrm{f}$ & $77.10 \mathrm{bc}$ & $16.33 \mathrm{~b}$ & $3.33 \mathrm{ab}$ & 0 & 0 \\
\hline SM220 & 42.00 ef & $72.33 \mathrm{~cd}$ & 13.00 ef & $6.67 \mathrm{ab}$ & 0 & 0 \\
\hline SM230 & $53.67 \mathrm{~b}-\mathrm{e}$ & $74.67 \mathrm{bc}$ & $13.67 \mathrm{~d}-\mathrm{f}$ & $3.33 \mathrm{ab}$ & 0 & 0 \\
\hline SM253 & $38.33 \mathrm{f}$ & $61.67 \mathrm{~d}$ & $16.00 \mathrm{bc}$ & $3.33 \mathrm{ab}$ & 0 & 0 \\
\hline SM253A & 42.33 ef & $80.67 \mathrm{bc}$ & $15.00 \mathrm{~b}-\mathrm{e}$ & $10.00 \mathrm{ab}$ & 0 & 0 \\
\hline SM262 & $77.33 \mathrm{a}$ & $105.33 \mathrm{a}$ & $10.33 \mathrm{~g}$ & $0 \mathrm{~b}$ & 0 & 0 \\
\hline SM275 & $49.33 \mathrm{c}-\mathrm{f}$ & $82.33 \mathrm{bc}$ & $13.67 \mathrm{~d}-\mathrm{f}$ & $0 \mathrm{~b}$ & 0 & 0 \\
\hline SM279 & 43.00 ef & $73.33 \mathrm{~cd}$ & $18.67 \mathrm{a}$ & $0 \mathrm{~b}$ & 0 & 0 \\
\hline SM289 & 43.00 ef & $73.33 \mathrm{~cd}$ & $19.00 \mathrm{a}$ & $3.33 \mathrm{ab}$ & 0 & 0 \\
\hline SM291B & 43.00 ef & $84.33 \mathrm{bc}$ & $15.67 \mathrm{~b}-\mathrm{d}$ & $0 \mathrm{~b}$ & 0 & 0 \\
\hline BARI Begun-6 & $59.00 \mathrm{bc}$ & $110 \mathrm{a}$ & $13.00 \mathrm{ef}$ & $3.33 \mathrm{ab}$ & 0 & 0 \\
\hline $\begin{array}{c}\text { Level of } \\
\text { significance }\end{array}$ & * & * & * & * & - & - \\
\hline CV (\%) & 15.49 & 9.44 & 9.36 & 144.35 & - & - \\
\hline
\end{tabular}

${ }^{*}$ Significant at $5 \%$ level of probability; ${ }^{*}$ Significant at $1 \%$ level of probability. Means in a column followed by the same letters are not significantly different at $1 \%$ level by DMRT.

Table 2. Qualitative characters of 18 eggplant lines/variety.

\begin{tabular}{ccc}
\hline Lines/variety & Fruit shape & \multicolumn{1}{c}{ Fruit colour } \\
\hline SM048 & Oblong & Light green with white spot at bottom \\
SM083 & Oblong & Light green with white spot at bottom \\
SM083A & Oval & Light green with white spot at bottom \\
SM083B & Oblong & Deep green with white spot at bottom \\
SM083E & Oval & Deep green with white spot at bottom \\
SM083F & Oblong & Deep green with white spot at bottom \\
SM083G & Oval & Light green \\
SM083H & Oval & Light green \\
SM220 & Oval & Light green with white spot at bottom \\
SM230 & Oval & Light green with white spot at bottom \\
SM253 & Oval & Deep green with white spot at bottom \\
SM253A & Elongate & Light green with white spot at bottom \\
SM262 & Round & Light green with white spot at bottom \\
SM275 & Elongate & Deep green with white spot at bottom \\
SM279 & Oval & Deep green with white spot at bottom \\
SM289 & Oval & Light green with violet shade \\
SM291B & Elongate & Light green \\
BARI Begun-6 & Oval & \\
\hline
\end{tabular}




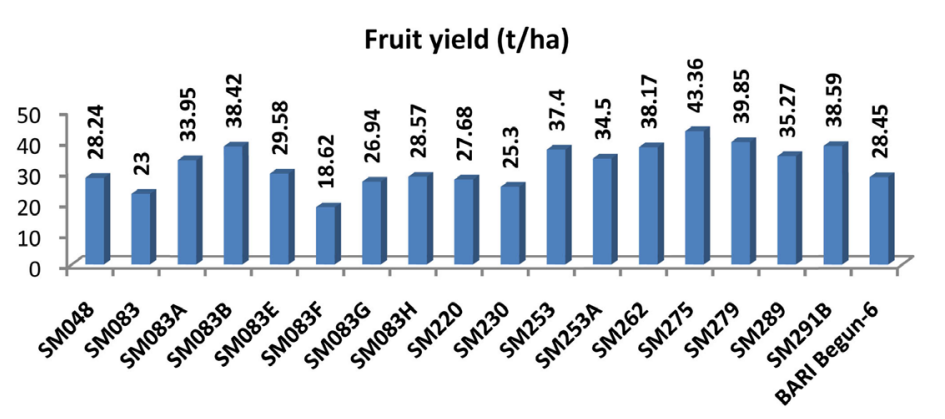

Figure 1. Fruit yield (t/ha) of 18 eggplant lines/variety.

SM289 (170 g), SM279 (169 g), SM083E (165 g), SM253 (164 g), while lightest fruit was in SM083F (68 g). Fruit weight/plant was maximum in SM275 $(3.94 \mathrm{~kg})$ which was statistically similar with SM279 (3.63 kg), SM 291B (3.51 kg), SM083B $(3.49 \mathrm{~kg})$, SM262 $(3.47 \mathrm{~kg}), \mathrm{SM} 253(3.40 \mathrm{~kg})$, while minimum was in SM083F $(1.69 \mathrm{~kg})$. The longest identical fruit was produced in SM083A $(17.33 \mathrm{~cm})$, SM083 $(17.10 \mathrm{~cm})$ which was statistically similar with SM083B $(15.17 \mathrm{~cm})$, SM291B $(15.83 \mathrm{~cm})$, SM275 $(14.67 \mathrm{~cm})$ and SM253A produced the shortest fruit $(8.33 \mathrm{~cm})$. The higher diameter identical fruit was produced by the line SM262 $(9.50 \mathrm{~cm})$, SM289 $(9.43 \mathrm{~cm})$ and minimum was by SM220 $(3.60 \mathrm{~cm})$. The range of plant height at first and last harvest was 38.33 - 77.33 days and $61.67-105.33$ days, respectively. The range of fruit infection by BFSB was $10.33-19.007 \%$, while lowest in SM262 (10.33\%), followed bySM083 (12.33\%), SM220 (13.00\%), SM048 (13.67\%), SM230 (13.67\%), SM275 (13.67\%) and highest was in SM289 (19.00\%). In case of bacterial wilt (BW) infestation at field level performance, zero percent incidence was observed in SM262, SM275, SM279, SM291B, while maximum was observed in SM083G (13.33\%). No infestation of little leaf disease and phomopsis blight diseases were observed in the lines. Morphological characteristics of the lines are presented in Table 2.

The yield range of eggplant lines was $18.62-43.36 \mathrm{t} / \mathrm{ha}$. The highest fruit yield was recorded from the line SM 275 (43.36 t/ha), which was statistically similar with SM 279 (39.85 t/ha), SM 291B (38.59 t/ha), SM083B (38.42 t/ha), SM 262 (38.17 t/ha), SM 253 (37.43 t/ha) and lower yield were recorded from SM 083K (18.82 t/ha). According to [9], maximum yield was obtained in variety Shamli (35.00 kg/plot-5 plant) and Eggplant deep black (35.50 kg/plot-5 plant) followed by Advanta 306 with values $32.05 \mathrm{~kg} /$ plot-5 plant. Least yield was measured in Xingchangjishi (17.45 kg/ plot-5 plant).

Four types of fruit shape was observed among the lines viz., oblong (4 lines), oval (10 lines/variety), elongate (3 lines), round (1 line), while in term of fruit colour, all the lines were green coloured with white spot at bottom except 5 lines/variety (SM083G, SM083H, SM289, SM291B, BARI Begun-6).

\section{Conclusion}

Though the yield of green coloured eggplant lines were generally lower compare to purple coloured eggplant, but consumer preferences is much higher than purple 
colour. Considering earliness, tolerance to fruit infection by BFSB, bacterial wilt infestation, attractive fruit shape and fruit colour, last of all fruit yield, the lines SM 275, SM 279, SM 291B, SM083B, SM 262 and SM 253 were found promising. So these six lines can be selected for further confirmation.

\section{Conflicts of Interest}

The authors declare no conflicts of interest regarding the publication of this paper.

\section{References}

[1] Thompson, H.C. (1951) Vegetable Crops. 4th Edition, MacGrew Hill Book Company Inc., London, p. 611

[2] Bose, T.K. and Som, M.G. (1986) Vegetable Crops in India. Nayaprakash, 206, Bidhan Sarani, Calcutta, p. 775.

[3] Anonymous (2017) Year Book of Agricultural Statistics of Bangladesh 2016. Bangladesh Bureau of Statistics, Ministry of Planning, Government of Peoples Republic of Bangladesh, Dhaka, 249-290.

[4] Streppel, M.T., Ocké, M.C., Boshuizen, H.C., Kok, F.J. and Kromhout, D. (2008) Dietary Fiber Intake in Relation to Coronary Heart Disease and All-Cause Mortality over 40 y: The Zutphen Study. The American Journal of Clinical Nutrition, 88, 1119-1125. https://doi.org/10.1093/ajcn/88.4.1119

[5] Megan Ware RDN LD (2017) Eggplant Health Benefits and Tasty Tips. Medical News Today.

[6] Rashid, M.A., Mondal, S.N., Ahmed, M.S., Ahmad, S. and Sen, D.K. (1988) Genetic Variability, Combining Ability Estimates and Hybrid Vigour in Eggplant (Solanum melongena L.). Thai Journal of Agricultural Science, 21, 51-61.

[7] Chadha, M.L. and Hegde, R.K. (1989) Combining Ability Studies in Brinjal. Indian Journal of Horticulture, 46, 44-52.

[8] Padmanabham, V. and Jagadish, C.A. (1996) Combining Ability Studies on Yield Potential of Round Fruited Brinjal (Solanum melongena L.). The Indian Journal of Genetics and Plant Breeding, 56, 141-146.

[9] Ashraf, H.M.I., Hassan, M.W. and Jamil, M. (2017) Evaluation of Different Brinjal (Solanum melongena L.) Varieties for Yield Performance and Sucking Insect Pests in Bahawalpur, Pakistan. Journal of Basic and Applied Sciences, 13, 437-441. https://doi.org/10.6000/1927-5129.2017.13.72 